\title{
INTERNATIONAL JOURNAL OF POLITICAL STUDIES
}

\author{
ULUSLARARASI \\ POLITIK ARAŞTIRMALAR DERGISİ \\ December 2017, Vol:3, Issue:3 \\ e-ISSN: 2149-8539 \\ Aralık 2017, Cilt:3, Sayı 3 \\ p-ISSN: 2528-9969
}

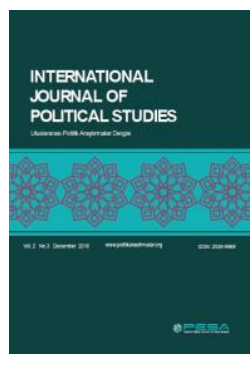

\section{AVRUPA BİRLİĞİ GÖÇ POLITIKKASI VE KİTLESEL GÖÇ AKINLARI KARŞISINDAKİ DURUMU}

\section{EUROPEAN UNION IMMIGRATION POLICY AND THE SITUATION AGAINST MASS IMMIGRATION}

Mehmet DURUEL

Yrd. Doç., Mustafa Kemal Üniversitesi, İ̈BF, ÇEEI Bölümü, duruel@mku.edu.tr

\begin{tabular}{l}
\hline MAKALE BİLGISİ \\
\hline \\
Geliş 17 Aralık 2017 \\
Kabul 21 Aralı 2017 \\
\hline Anahtar Kelimeler: \\
Avrupa Birliği \\
Göç \\
Suriye
\end{tabular}
ÖZET

Ekonomik işbirliği temeline dayalı bir organizasyon olarak ortaya çıkan AB (Avrupa Birliği), ilerleyen süreçte siyasi ve sosyal bütünleșmeyi de kapsayan hedefler belirlemiş ve bu hedefler doğrultusunda çeşitli düzenlemeler gerçekleştirmiştir. $\mathrm{Bu}$ düzenlemelerden birisi de göç politikasıdır. Birlik üyesi ülkelerin ekonomik, politik ve sosyal alanlarda dünyanın çoğu bölgesinden daha ileri seviyede olması ve müreffeh bir hayat sunması göçmenler bakımından bu ülkeleri son derce cazip kılmaktadır.

İșsizlik ve düşük hayat standartlarından daha aktif bir iș piyasası ve bașta eğitim olmak üzere daha kaliteli ve müreffeh bir hayat yaşamak amacı ile bireysel ve göreli olarak daha düşük sayılarla $\mathrm{AB}$ üyesi ülkelere yönelen göçler karşısında başlangıçta ortak bir düzenlemeye gerek duyulmamıştır. Üye ülkelerin kendi talepleri ile davet ettiği işgücü, politik gerekçeli iltica talepleri ya da eğitim amaçlı süresi belirli göçmenler için $\mathrm{AB}$ temel prensiplerine aykırılık teşkil etmemek kaydıyla her ülke kendi düzenlemelerini kendisi yapmış ve hayata geçirmiş̧ir. Ancak ilerleyen süreçte göçmen kitlesinin nitelik ve nicelik olarak değişim göstermesi ve $\mathrm{AB}$ sosyal politika uygulamalarını tehdit etmesi $\mathrm{AB}$ 'nde bu alanda ortak politikalar oluşturma yönünde düzenlemeler yapılmasına neden olmuştur.

$\mathrm{Bu}$ çalı̧̧mada $\mathrm{AB}$ ortak göç düzenlemelerinin gelişimi ve son dönemlerde özellikle orta doğu bölgesindeki politik istikrarsızlıklar ve savaș ortamından kaynaklanan kitlesel göç hareketleri Suriyeli Sığınmacılar özelinde incelenecektir. AB göç politikalarının Suriyeli Sığınmacılara yönelik tepkisel önlemleri AB'nin başta insan hakları olmak üzere diğer evrensel değerleri ile ne

(C) 2017 PESA Tüm haklarl saklddır derece örtüştüğü sorgulanacaktır.

\begin{tabular}{l}
\hline ARTICLE INFO \\
\hline Received 17 December 2017 \\
Accepted 21 December 2017 \\
\\
\hline Keywords: \\
European Union \\
Migration \\
Syria \\
\hline
\end{tabular}

\section{ABSTRACT}

European Union (EU), which is based on an organization about economical cooperation, has determined targets which includes social and politics integration in the progress duration and makes the different arrangement in the direction of these targets. One of these arrangements is the migration policies. These countries are attractive because these country have advanced level about economical,politics and social area from the most of the other countries and they can offer comfprtable live for the immigrants.

At the beginning it has not seem necessary to make any arrangement aganist the migration which is oriented to the EU countries with small and individually numbers to have good living conditions and have good education and have a work market which is more active than the unemployment and low living standarts. Every country makes its own arrangement and apply these policies about the labor that they invite, request politic asylum or refuges for specific education without making any contradiction to the basic principles of EU. But at improving duration because the quality and quantity of the immigrant change and it threaten the EU's politics social applications, it causes to make common arrangements about this area.

In this study the improvement of the common migration arrangement of EU, instability policies in the Middle East at the last term, mass of the migration which is caused from the war enviroment will be examined on specifically Syrian Refuges. It is going to be questioned how the reactive preventions of the EU 's migration policies aganist the Syrian Refuges overlap with the EU's universal values especially human rights. 


\section{GÍRİ̧}

Göç, mülteci, sığınmacı sorunu son dönemlerde insanlığın karşı karşıya kaldığı en önemli meselelerden biridir. Birleşmiş Milletler verilerine göre 300 milyona yakın insan, yani dünya nüfusunun yüzde 3'ü kendi ülkeleri dışında yaşamaktadır. Aynı verilere göre ülkelerin nüfuslarına göre sıralanması durumunda 196 ülke arasında dünyanın 21 büyük ülkesinin göçmenler ülkesi olacağı ifade edilmektedir. $\mathrm{Bu}$ durum göç olgusunun nedenleri ve sonuçları ile toplumları, devletleri ve onların ortaya koyduğu politikaları ciddi şekilde etkilediği küresel bir insanlık sorunu haline geldiğini ortaya koymaktadır.

Tarihin her döneminde toplumları derinden etkileyen göç hareketlerinin varlığına tanık olunmuștur. Söz konusu göçlerin sebepleri, sonuç ve tesirleri yaşandıkları dönemin siyasi, ekonomik ve toplumsal ilişkileri ile yakından ilintilidir. İnsanlar çeşitli nedenler sonucu kendi ülkelerini terk edip başka ülkelere göç etmekte ve göç edilen ülkeler göçün doğurduğu sonuçlara yönelik çeşitli politikalar üretmek durumunda kalmaktadırlar. Bu politikalar göçmen ve sığınmacıları kabullenen, yapıcı ve içselleştirici karakterde olabileceği gibi, reddiyeci ve dışlayıcı da olabilmektedir.

Kadim bir göç geçmişine sahip coğrafyada ekonomik işbirliği temeline dayalı bir organizasyon olarak ortaya çıkan AB (Avrupa Birliği), ekonomik, politik ve sosyal alanlarda dünyanın çoğu bölgesinden daha ileri seviyede olması ve müreffeh bir hayat sunma iddiası nedeniyle göçmenler bakımından son derce cazip bir alan olarak görülmüştür. Son dönemlerde Arap Baharı ile tetiklenen kitlesel göç akınlarının hedef coğrafyası haline gelen AB'nin, gelişim sürecinde siyasi ve sosyal bütünleşmeyi de kapsayan düzenlemelerinden birisi de göç politikasıdır.

İşsizlik ve düşük hayat standartlarından daha aktif bir iş piyasası ve başta eğitim olmak üzere daha kaliteli ve müreffeh bir hayat yaşamak amacı ile bireysel ve göreli olarak daha düşük sayılarla $\mathrm{AB}$ üyesi ülkelere yönelen göçler karşısında başlangıçta ortak bir düzenlemeye gerek duyulmamıştır. Üye ülkelerin kendi talepleri ile davet ettiği işgücü, politik gerekçeli iltica talepleri ya da eğitim amaçlı süresi belirli göçmenler için $\mathrm{AB}$ temel prensiplerine aykırılık teşkil etmemek kaydıyla her ülke kendi düzenlemelerini kendisi yapmış ve hayata geçirmiştir. Ancak ilerleyen süreçte göçmen kitlesinin nitelik ve nicelik olarak değişim göstermesi ve $A B$ sosyal politika uygulamalarını tehdit etmesi, $A B$ 'nde bu alanda ortak politikalar oluşturma yönünde düzenlemeler yapılmasına neden olmuştur.

$\mathrm{Bu}$ çalışmada $\mathrm{AB}$ ortak göç düzenlemelerinin gelişimi ve son dönemlerde özellikle orta doğu bölgesindeki politik istikrarsızlıklar ve savaş ortamından kaynaklanan kitlesel göç hareketleri Suriyeli Sığınmacılar özelinde incelenecektir. AB göç politikalarının Suriyeli Sığınmacılara yönelik tepkisel önlemleri AB'nin başta insan hakları olmak üzere diğer evrensel değerleri ile ne derece örtüştüğü sorgulanacaktır.

\section{Avrupa Birliği Göç Politikasının Oluşumu}

İkinci Dünya Savaşı'na kadar "göç gönderen” konumda olan Avrupa ülkeleri, 20. yüzyılın ikinci yarısından itibaren göç alan topraklar haline gelmiş, buna paralel olarak kendi göç politikalarını oluşturmaya başlamıştır (Canpolat ve Arıner, 2012: 12). AB'nde üye ülkelerin hangi şekilde ve şartlarda mülteci kabul edeceği, kimlere mülteci statüsü vereceği hususu uzun yıllar üyelerin kendi yetki ve düzenleme alanında bulunmuştur. $\mathrm{AB}$ üyesi olan ülkelerin entegrasyonu arttıkça iltica ve göç hususları, AB'nin tartıştığı önemli konular arasında yerini almıştır. Bu tartışmalar, AB'nin mültecilerle ilgili ortak hukuki kurallar ve politikalar üretmesi gerektiğini ortaya koymuştur. Süreç içerisinde üye devletlerin $\mathrm{AB}$ çatısı altında sığınma ve göç politikalarıyla ilgili ortak düzenlemeler yapmaya başladığı görülmüş̧ür. $\mathrm{Bu}$ kapsamda üye devletler taraf oldukları uluslararası antlaşmaların ve $\mathrm{AB}$ düzenlemelerinin hükümlerini kendi iç hukuk düzenlerine yerleştirmişlerdir (Dürgen, 2015: 25). Böylesine geniş süreç bütün $\mathrm{AB}$ üyelerinin ve dolayısıyla birlik açısından vatandaş olmayanlara ilişkin şartlarla birlikte etnik yapı, ekonomi ve ulusal güvenlik gibi önemli hususları da yeniden şekillendirmektedir (Akalın, 2013: 51).

İkinci Dünya Savaşı sonrası başta ekonomi olmak üzere her alanda yıkıma uğramış Avrupa ülkeleri, hızlı bir şekilde gelişmek adına tekrar bir mücadeleye başlamıştır. Ülkelerini kalkındırma adına bütün gayretlerini gösteren Avrupa Ülkeleri çok çalışmakla beraber artan işgücü ihtiyacını karşılamak için "açık kapı" politikası uygulanmaya başlanmıştır. Bu kapsamda gelişmemiş ülkelerden Avrupa ülkelerine göç başlamış olup, söz konusu konu göç akımı 1945-1973 yılları arası devam etmiştir. Açık 
kapı politikası olarak ifade edilen döneminde pek çok göçmen işçi Avrupa ülkelerine çalışmak üzere gitmiştir (Savaşan, 2009: 19). Bu süreç henüz ortak göç ve iltica düzenlemelerine ihtiyaç duyulmadığ bir dönem olarak bilinmektedir.

AB Ortak Göç Politikası (OGP), ilk olarak AET Kurucu Anlaşması olan 1957 Roma Antlaşması'nın kişilerin, hizmetlerin ve sermayenin serbest dolaşımına ilişkin hükümlerinin bulunduğu III. Başlıkta ele alınmıştır. Buradaki temel amacın altında, yerleşme ve çalışma özgürlüğünün sağlanarak Birlik ülkelerinin sahip oldukları içsel emek potansiyelinden maksimum düzeyde yararlanabilmek yatmaktadır. Ancak, AB ülkelerinin hedeflediği içsel emek hareketliliği toplam göç yoğunluğu içinde oldukça düşük bir oranda kalmaktadır (Gençler, 2005: 184).

1973 yılında dünyada ortaya çıkan ve büyük ekonomik sorunlara neden olan petrol krizi sebebiyle, açık kap1 politikası yerini "kapalı kapı" politikasına bırakmıştır. 1970'li yıllarda bir yandan ekonomik krizlerin etkisiyle girilen durgunluk dönemlerinin yükselttiği işsizlik oranları, diğer yandan yeni gelişen üretim teknolojilerinin ihtiyaç duyduğu işçi profilinin değişmesi ile dışarıdan geniş ölçeklerle işçi kabul edilmesi sürdürülebilir olmaktan çıkmıştır. Bu nedenle, ülkeler bazında çeşitli tedbirler alınmaya başlanmıştır. Diğer yandan, bu süreçte aile birleşmeleri yoluyla ya da siyasi sığınma talepleri ile gelişler devam etmiş, göçün istenildiği zaman kolayca durdurulabilecek bir olgu olmadığı anlaşılmaya başlanmıştır (Samur, 2008: 4). Serbest piyasanın özellikle Ortak Pazarın gerektirdiği mal, hizmet, sermaye ve emek dolaşımının serbest kalmasıyla birlikte, göçmen ve sığınmacılar artık insani yardım ve koruma gerektiren veya işçi göçmenleri gibi ekonomik bir amaca hizmet eden kişiler olarak değil, devletin sosyal hizmetlerinden yararlanmaya çalışan veya sosyal düzeni tehlikeye sokan, sınırlara tehdit oluşturan kişiler olarak görülmeye başlanmıştır (Canpolat ve Arıner, 2012: 13). Bu süreç göç ve iltica konusunun $\mathrm{AB}$ düzeyinde ele alınması gerekliliğini gündeme getirmiştir.

\subsection{Schengen Anlaşması}

Göç konusunda hükümetler arası işbirliğinin ilk sonucu 1985 yılında Avrupa Toplulukları üyesi 5 ülke (Belçika, Fransa, Almanya, Lüksemburg ve Hollanda) tarafından imzalanan Schengen Anlaşması" olmuştur. Söz konusu anlaşma, bir yandan imzacı devletlerin ortak sınırlarındaki kontrolleri yavaş yavaş kaldırırken, diğer yandan dış sınırları üzerinde denetimleri güçlendirmiştir (Güleç, 2015: 85). Sözleşmeye bakıldığı zaman istenmeyen göçmenlerin ve sığınmacıların legal girişine imkan vermeyecek kural ve şartların konulduğu görülmektedir. Anlaşma ile iç ve dış güvenlik önlemleri ile dışarıdan gelmesi muhtemel mültecilerin girişleri engellenmektedir. Bu açıdan bakıldığı zaman fiilen Avrupa topraklarına girmemiş şahsın Avrupa Birliği'ne sığınmacı olarak başvurması kendi hukukları kapsamında da mümkün değildir. Ayrıca, Avrupa Birliği "taşıyıcıların sorumluluğu(carrier sanctions)" uygulaması ile beraber sığınmacıları taşıyacak firmalara yüksek miktarda para cezası vererek herhangi bir belge temin edemedikleri için mülteci başvurusunda bulunamayan mağdurların seyahat hakları ellerinden alınmaktadır. Söz konusu uygulamaların insan haklarını engelleyecek ölçüde sert olmasından hareketle, 1951 tarihli Cenevre Sözleşmesi ve 1967 Protokolü’nde yer alan “geri göndermeme ilkesi”nin açıkça aykırı olduğu görülmektedir (Ünlü, 2007: 135). Öte yandan, Avrupa Birliği üyeleri tarafindan hazırlanan Schengen Bilgi Sistemi de sığınmacıların aleyhine olarak uygulanmaktadır. Normal şartlar altında kural gereği herhangi bir $\mathrm{AB}$ üyesi içinde yakalanan kamu düzeni ve ulusal güvenlik açısından tehlike oluşturan kimseler sisteme kaydedilmektedir. Ancak, AB üyesi ülkelerin, suç işlemedikleri halde sınırlarına illegal giren veya sığınma talebi reddedilen sığınmacıları sisteme kaydettiği görülmektedir (Özcan, 2005: 41-47). Avrupa ülkeleri tarafindan kurulan elektronik sisteme kaydı olan sığınmacıların ise Schengen'e taraf olan hiçbir ülkeye girme şansları bulunmamaktadır. Bu gelişmeler 1şığında, insan hakları savunucuları tarafından "Avrupa Kalesi (Fortress Europe)" yaratılmaya çalışıldığı şeklinde değerlendirmeler yapılarak eleştirilmektedir (Kirişçi, 2002: 72).

\subsection{Dublin Sözleşmesi}

1990'lı yılların başında Sovyetler Birliği'nin dağılması, balkanlardaki gerginlikler, Yugoslavya'nın parçalanması ve Bosna Hersek işgali olayları sebebiyle $A B$ ülkelerine yönelik ciddi göç kitlesi oluşmuş̧tur. $\mathrm{Bu}$ durum ise $\mathrm{AB}$ üyesi ülkeler arasında mültecilik ve göçmenlik konularında ciddi görüş farklılıkları ortaya çıkarmış ve zaman zaman tartışmalara sebep olmuştur (Ünlü, 2007: 136). Sığınmacı rakamlarındaki artış sebebiyle, $\mathrm{AB}$ üyesi devletlerin sorumluluk alanlarının tespit edilmesine yönelik olarak Dublin Sözleşmesi (Dublin-1) kabul edilmiştir. Sözleşmenin daha sonra topluluk sütununa 
aktarılmasıyla Dublin Tüzüğü meydana gelmiştir (Akalın, 2013: 56). Dublin Sözleşmesi genel itibariyle Schengen Sözleşmesi'nin içinde yer alan sığınma taleplerine ilişkin kuralları taşımaktadır. Bununla beraber, şartların belirlenmesindeki sorumlu ülkenin tespitine ilişkin daha kapsamlı açıklamalara yer verilmiş olup, siyasi sığınmacının kim olduğu hakkında da uzlaşıımıştır (Ünlü, 2007: 136). Schengen Sözleşmesi'ne benzer şekilde Dublin Sözleşmesi de Avrupa Topluluğu Adalet Divanı (ATAD)'ın hukuki denetimine tabi değildir. Bundan dolayı, Schengen Sözleşmesi ile Dublin Sözleşmesi arasında herhangi bir çatışma yaşanmaması amaciyla Dublin Sözleşmesi'nin 01.09.1997'de yürürlüğe girmesiyle beraber, Schengen Sözleşmesi'nin sığınma ile ilgili olan bütün hükümleri ortadan kalkmıştır (Akalın, 2013: 56). Öte yandan, Dublin Sözleşmesi, sığınma taleplerinin içeriği ile ilgilenmemekte, yalnızca sığınmacıların $\mathrm{AB}$ üye devletlerinin topraklarına girişi ve başvuru koşulları dikkate alınarak sorumlu ülkeyi tespit etmektedir (Ünlü, 2007: 136). Söz konusu şartlar masaya yatırılıp, akabinde sıranın başından başlamak suretiyle sığınmacının hangi şarta uyduğuna bakarak, sorumlu ülke tespit edilmektedir (Akalın, 2013: 56). Söz konusu hiyerarşik sıra ise: Aile birleşimi(sı̆̆ınmacının ailesinin bulunduğu ülke sorumludur), -Oturma izninin olduğu ülke, -Vize aldığı ülke,-İllegal giriş yaptığı ülke, -Legal giriş halinde girişin ilk kabul edildiği ülke, -Bunların hiçbirinin uymadığı(elçiliğe başvuruda bulunma gibi özel durumlarda) sığınma başvurusunun yapıldığı ülke olarak belirlenmiştir (Ünlü, 2007: 136). Diğer taraftan, Dublin Sözleşmesi, AB üyelerini birleştiren ortak bir mülteci tanımına ulaşmadan, ortak ilke ve şartları belirlemeden $\mathrm{AB}$ üyelerinin sığınma başvurularına yönelik kararlarını standart hale getirmeye çalıştığ 1 için etkisiz bir düzenleme görünümü sergilemiştir. Sözleşme, sığınmacıların başvurularını istedikleri ülkeye yapmalarını engellemektedir. Ayrıca, sığınmacıların bir AB ülkesinden diğerine yönelik seyahatini engellemek üzere tasarlandığ 1 ifade edilmektedir. $\mathrm{Bu}$ ve buna benzer örnekler ve tespitler ışığında Dublin Sözleşmesi'nin sığınmacıların temel haklarını engelleyici bir yapıya da sahip olduğu değerlendirilmeleri yapılmaktadır.

Her ne kadar Schengen ile sınırları kaldırıp serbest dolaşım imkânı sağlamış, Dublin Sözleşmesi ile de sığınma konusunda çalışmalar yapmış olsa da bunların üye devletlerin ulusal mevzuatlarında uygulanması konusunda büyük anlaşmazlıklar ortaya çıkmıştır. Söz konusu bu anlaşmazlıklar ve Avrupa Birliği üyesi ülkelerin iltica ve mülteci konusunda birlik olarak ortak karar alamama sorunu devam etmiştir.

\subsection{Maastricht Antlaşması}

$\mathrm{AB}$ düzeyinde yoğunlaşan hükümetler aras1 işbirliği, topluluğun bütünleşme süreci ve göç ve iltica konularındaki hükümetler arası işbirliğinin Topluluk düzeyine taşınmasına neden olmuştur. 1992 senesinde imzalanan ve 1993'te yürürlüğe giren Maastricht Antlaşması çerçevesinde Avrupa Topluluğu “Avrupa Birliği” adını almış ve AB'nin “üç temel sütun”u oluşturulmuştur. Antlaşmanın AB’nin göç politikası açısından en önemli noktası ise, Antlaşmadan önce devletler arası koordine edilen oluşumları kurumsal olarak birleştirmesi ve AB'nin üçüncü temeli olan "Adalet ve İçişleri” alanına entegre etmesidir (Canpolat ve Arıner, 2012:13). Bu çerçeveden bakıldığında Maastricht Antlaşması'nın en önemli özelliği, bu konularda hükümetler arası işbirliğini ön görmesinin yanı sıra, bu alanda $\mathrm{AB}$ organlarına da yetki vermesidir. Böylece, göç ve iltica politikalarında Topluluk çapında ve düzeyinde çalışmalar yoğunlaşmaya başlamıştır (Somuncu, 2006: 46).

Maastricht Antlaşması'nın getirdiği düzenlemeler ile her ne kadar içişleri ve yargısal konularda AB üyelerini birleştirici bir yapıya sahip olsa da sığınma hususunda pek fark olmadığı görülmektedir. Sı̆̆ınma politikası hususunda çok sayıda çalışmalar yapılmış olup, AB üyesi ülkeler söz konusu çalışmalardan "Sığınma Prosedürleri için Asgari Teminatlar Hakkında Konsey Kararı"nda ulusal kanunlarını karardaki hükümlerle uyumlaştırmayı kabul etmişlerdir. Ancak, sığınma politikası hususundaki ulusal mevzuatların tamamı ile uyumlaştırılması gerekirken, çok az düzeyde anlaşma sağlayabilmişlerdir (Savaşan, 2009: 20).

\subsection{Amsterdam Antlaşması}

AB üyeleri tarafindan Ekim 1997'de imzalanan Amsterdam Antlaşmas1, 1999 yılında yürürlüğe girmiştir. AB'nin sığınma politikasının gelişiminde bir dönüm noktası olarak Amsterdam Antlaşması ile beraber sığınmayla ilgili yaşanan sıkıntıların çözümünde $\mathrm{AB}$ üyelerinin aralarında yapacakları 
antlaşmalar belirleyici olmaktan çıkarılmıştır. Bunun yerine sığınmacı sorunu ile ilgili politika geliştirme ve karar alma yetkisinin $\mathrm{AB}$ kurumlarına devredilmesi gündeme getirmiştir. Söz konusu anlaşmayla beraber, $A B$ 'nin sığınma ile ilgili hususlarda hangi alanlarda yetkili olacağı belirlenmiş ve 5 yıllık bir geçiş süreci hedeflenmiştir (Dürgen, 2015: 26-27). AB üyelerinin sığınmacı konusundaki külfetlerinin paylaşımı, uzun süreli oturum ve vize verilmesine ilişkin karar ve $\mathrm{AB}$ üyesi ülkede ikamet eden üçüncü ülke vatandaşlarının hangi şartlarda diğer üye ülkelerde ikamet edebileceğini düzenleyen kararlar ise 5 yıllık geçiş sürecinde istisna tutulmuştur. Söz konusu geçiş sürecinde AB Komisyonu'nun yasa teklif etme yetkisini üye ülkelerle paylaşacağı, bu süre sonunda ise üye ülkelerden gelecek muhtemel teklifleri dikkate almak durumunda olacağı belirtilmiştir. Bu şekilde yapılan düzenlemeyle sığınma ile ilgili alınacak hükümlerin $\mathrm{AB}$ üyeleri tarafından denetlenip, sınırlandırılabileceği anlaşılmaktadır. Ancak bu konu kapsamında İngiltere, İrlanda ve Danimarka'ya bazı ayrıcalıklar tanınmış olup, bu ayrıcalıklar hem idari hem de yasal karmaşalara sebep olmuştur (Savaşan, 2009: 22). Öte yandan, AB üyeleri arasında başlatılan Schengen Sözleşmesi de 1999 yılında onaylanarak yürürlüğe giren Amsterdam Antlaşması'na ekli bir protokolle Topluluk sütununa aktarılmış olup, sözleşme AB hukukunun bir parçası olmuştur. Bu şekilde, Schengen Sözleşmesi de AB'nin ikincil hukuk hükümleri haline gelmiștir. Amsterdam Antlaşması ile öngörülen 5 yıllık geçiş süreciyle bağlantılı olarak, yine 5 yıllık süre için geçerli olacak şekilde Avrupa Mülteci Fonu oluşturulmuştur (Savaşan, 2009: 22).

\subsection{Tampere Zirvesi}

Schengen ve Amsterdam düzenlenmeleriyle $A B$ hukukunun sığınma hususunda genel çerçevesi belirlenmiştir. Herhangi bir mülteci ve sığınmacı akınına karşılık olarak AB'nin dış sınırları güçlendirilmiş ve sığınma prosedürü belli bir standarda ulaşmıştır. 1998 yılında toplanan $\mathrm{AB}$ Komisyonu, BMMYK ve uluslararası sivil toplum örgütleri tarafından 1951 Mülteci Sözleşmesi ile getirilen düzenlemeleri zayıflattığı gerekçesiyle eleştirilmiştir (Taneri, 2012: 314). Bunun üzerine, AB Komisyonu, Ekim 1999 ayı içinde Finlandiya'nın Tampere şehrinde toplanarak "sığınma arama hakkına tam olarak saygı" hususunda anlaşmışlardır (Dürgen, 2015: 27). Bu toplantıda AB üyelerinin "Ortak Avrupa Sığınma Sistemi” oluşturulmasına karar verilmiştir (Taneri, 2012: 314). Buna göre, bir kişinin zulüm gördüğü yere geri gönderilmemesi ilkesine gerçek manasıyla uyulacağı Ortak Avrupa Sığınma Sistemi (OASS) kurma hususunda anlaşmaya varılmıştır. Buna göre ilk etapta sığınma talebini inceleyecek ülke tespit edilecektir. Daha sonra, adil ve etkin bir sığınma prosedürü kurulması amacıyla sığınmacıların taleplerinin inceleneceği standartların belirlenmesi planlanmıştır. AB üyeleri, sığınmacıların belirlenmesi ve kabul edilmesi konularındaki asgari ortak şartlardan, geçici koruma ve yardımcı korumaya kadar birçok hususta ivedi tedbirler alacaklarını ifade etmişlerdir. Bu önlemleri tabi olduğu ülke ya da transit geçiş yaptığı ülkenin siyaset, insan hakları ve kalkınma ile ilgili sorunlarına yönelik kapsamlı bir yaklaşıma dayandırmışlardır (Dürgen, 2015: 27). Ortak bir sığınmacı sistemi kurulması amacıyla hazırlanan Tampere Toplantısı'nda idari anlamda tek bir yere bağlı bir sistem kurulmamıştır. Söz konusu toplantıda kurulmak istenen sistem, önceden belirlenmiş prosedür ve şartlara bağlı sistematik bir göç politikasının hazırlanmasıdır.

\subsection{Lahey Programı}

Lahey Programı, 1999 yılındaki Tampere Zirvesi'nin ardından özgürlük, güvenlik ve adalet alanında 2000-2004 yılları arasında ulaşılması hedeflenen çizginin devamını oluşturmaktadır. Yani, AB'nin göç ve iltica alanda 2005-2010 yılları arasında gerçekleştirmek istedikleri hedefleri oluşturmaktır. Lahey Programı'nın düzenlenmesinin amacı; "1951 tarihli Cenevre Sözleşmesi ve diğer uluslararası anlaşmalara uygun olarak, ihtiyaç halindeki kişilerin temel haklarını, asgari usul korumalarını ve adalete erişimlerini sağlamak, göç akışlarını düzenlemek ve Birliğin dış sınırlarını kontrol etmek, sınır aşan organize suçlarla mücadele etmek ve terörizm tehdidini bastırmak, Europol ve Eurojust'in potansiyellerinin farkına varmak, adli kararlar ile diğer özel hukuk ve adli konulardaki belgelerin karşılıklı tanınmasını ileri götürmek ve sınır aşan etkilere sahip özel hukuk ve aile konuları ile ilgili yasal işlemlerde karşılaşılan hukuki ve adli engelleri ortadan kaldırabilmek için Birlik ve üye devletlerinin ortak yeteneklerini geliştirmektir" (Köktaş, 2011: 12). 
Lahey programı ile birlikte Avrupa Konseyi, göç politikasının dış boyutuna ilişkin olarak, özellikle Akdeniz ve Afrika'ya özel önem atfederek, 13.12.2005 tarihli “Göçe Küresel Yaklaşım” yönergesini kabul etmiştir. $\mathrm{Bu}$ yaklaşımla beraber; illegal göçle mücadele, yasal ve ekonomik göçü teşvik etmek, sığınmacıların çalışma ve ikamet izinlerinin düzenlenmesi, $\mathrm{AB}$ ve diğer ülkeler arasında döngüsel göç kurmak gibi ilkeleri AB göç politikasının merkezine yerleştirmiş̧ir. Ayrıca, söz konusu yaklaşım, hem düzensiz göçe hem de üçüncü ülkelerle işbirliğine ilişkin kapsamlı bir strateji öngörmüştür. $\mathrm{AB}$, göçün kendisinden daha çok göçe iten faktörlere odaklanmaya çalışarak menşei ülkelerle işbirliği yolları üzerinden bir strateji yapmayı amaçlamıştır. (Elmas, 2016: 43-44).

\subsection{Stockholm Programı}

2010 yılından sonra Lahey Programı'nın yerini Stockholm Programı almıştır. Program, Temmuz 2009 ayı içinde Stockholm'de düzenlenen resmi olmayan bakanlar toplantısında tartışılmış olup, AB Devlet ve Hükümet Başkanları tarafından Aralık 2009 ayı içinde kabul edilmiştir. Stockholm Programı Komisyon Belgesi, AB içinde adalet güvenlik ve özgürlük alanının güçlü bir dış yapılanmayla beraber olacağı belirtilmekte ve AB'nin inşasının dört temel öncelik üzerine kurulacağı ifade edilmektedir. Buna göre, vatandaşların haklarının korunması, $\mathrm{AB}$ içindeki vatandaşların mahkemelere erişim haklarının kolaylaştırılması, vatandaşların korunması bağlamında yerel güvenlik stratejilerinin geliştirilmesi, özellikle yasal göçmenleri ilgili olarak $\mathrm{AB}$ üyeleri ve $\mathrm{AB}$ dışındaki devletler ile kurulan ortaklıklarda dayanışma ilkesinin desteklenmesi üzerine kurulan önceliktir (Sönmez, 2015: 222).

Stockholm Programı'nda özelikle dayanışma ilkesinin kuvvetlendirilmesi amaçlanmıştır. Bu kapsamında özellikle sınırlardaki kontrolün artması ve AB'de daha güvenli bir ortamın sağlanması amacıyla FRONTEX işbirliği ve Schengen Sözleşmesi'nin geliştirilmesi ile birlikte sinırlardaki güvenlik, göç ve gümrük hususlarında daha somut adımlar atılmaya başlanmıştır. Frontex dışında Dublin sistemindeki diğer iki birim ise, Avrupa İltica Destek Ofisi (The European Asylum Support Office/ EASO) ve EURODAC'tir. EASO, ortak bir iltica sisteminin oluşturulmasında görevliyken; EURODAC, 14 yaşından büyük sığınmacıların parmak izlerinin alınarak kimliklerinin kayıt altına alınmasıyla oluşturulan bir sistemdir. Stockholm Programı'nda 2005 yılında öne sürülen göç hususunda küresel yaklaşımın uygulamaya konulmasına ilişkin düzenlemeler de yer almaktadır (Sönmez, 2015: 222-223).

Bütün bu gelişmeler değerlendirildiğinde Avrupa Birliği'nin göç, sığınma ve iltica konularında yapmış olduğu çalışmaların çok da başarılı olmadığı görülmektedir. Nitekim Suriye'de meydana gelen iç savaş neticesinde milyonlarca kişinin yaşadığ ülkeyi terk etmesine ve sığınmacı durumuna düşmesine yol açmıştır. $\mathrm{Bu}$ insanlar can güvenliklerini sağlamak ve daha iyi şartlarda yaşamak için $\mathrm{AB}$ üyesi ülkeleri sığınılacak liman olarak görmüşlerdir. Sahip olduğu yüksek ekonomik seviyenin yanında dünyaya vadettiği insan hakları, hukukun üstünlüğü, herkes için demokrasi gibi değerler sığınma konusunda göçmenleri cezbetmiştir. Milyonlarca mülteciyi bir anda sınırlarında gören Avrupa Birliği ülkeleri yeni bir mülteci sorunu ile karşı karşıya kalmıştır. Söz konusu bu sorunu çözmek adına birlik üyesi ülkeler yeni politikalar geliştirmek zorunda kalmıştır. Birlik, yeni politikalarında göç sorununa çözüm bulmak yerine daha çok bunu Avrupa dışında tutmak ve orada yönetmek istemiştir (Turan ve Şaşkın, 2017: 50).

\section{Kitlesel Göç Akınları Karşısında AB Göç Politikasının Durumu}

Kitlesel göç akınları karşısında AB'nin tutumu hem kendi değerleri ile hem de bağlı olduğu uluslararası hukuk düzenlemeleri ile çelişmektedir. Ekonomik entegrasyon olarak ortaya çıkıp, sosyal devlet prensipleri çerçevesinde halkalarına müreffeh bir hayat sunmayı, farklılıkları zenginlik olarak gören sosyokültürel yaklaşımı, insanı merkez alan ve tüm insanlar için insan onuruna yakışır hayat standartlarını ilke edinen $\mathrm{AB}$, kapısına dayanan milyonlarca sığınmacıyı sınırları dışında tutmanın arayışına girmiştir. Yine gerek uluslararası platformda imzaladığı Cenevre Sözleşmesi, gerekse Birlik kapsamında imzaladığı hukuki düzenlemelere aykırı olarak sığınmacıları kendi sınırları dışında tutuma gayreti farklı politikalar geliştirmiştir. Bu politikaların iki önemli ortak noktası vardır. Bunlardan birincisi her halükarda kitlesel sığınma talepleri bir şekilde geri çevrilmekte ve AB sınırlarına sığınmacı 
girişi engellenmektedir. İkincisi, sığınmacılarla ilgili her türlü ekonomik, sosyal, kültürel ve güvenliğe ilişkin riskler Birlik sınırlarının dışında komşu ya da yakın ülkeler eliyle bertaraf edilmektedir.

AB'nin kitlesel göç akınları karşısında geliştirdiği politikalardan ilki “Geri Kabul Anlaşmaları”dır. Geri kabul anlaşmaları; bir ülkeye yasadış1 yollardan giriş yapmış ve genellikle yasalar ile belirtilmiş olan gümrük kapıları ile diğer giriş noktalarından sayılmayan yerlerden ülkeye girmiş ve halen ülkede bulunan kişiler ile bunların dışında giriş sırasında tüm bu şartları sağlamış olsalar bile, vize süresinin bitmesi veya buna benzer nedenlerle artık söz konusu şartları taşımadıkları için bu kişilerin vatandaşı oldukları ülkelere gönderilmelerine yönelik düzenlemeleri içeren anlaşmalardır (Çelik, 2014: 1). Aslında geri kabul anlaşmaları Avrupa devletlerinin uzunca bir süredir uygulayageldiği bir yöntemdir. Avrupa devletleri 19. Yüzyılın başından İkinci Dünya Savaşı'na kadar olan süreçte birçok geri kabul anlaşması imzalamıştır. Söz konusu imzalanan bu anlaşmalar daha çok savaş sonrasında yerinden edilmiş insanların geri kabulleri için oluşturulmuştur. Bu bağlamda İkinci Dünya Savaşı geri kabul anlaşmaları bakımından dönüm noktası olmuştur (Hacıoğlu, 2016: 411). Çünkü ilk geri kabul Antlaşmaları daha çok ülkelerin kendi vatandaşlarını geri kabul etmelerine ilişkinken, daha sonraki Antlaşmalarda üçüncü ülke vatandaşlarının geri kabulü düzenlenmeye başlamıştır (Hacıoğlu, 2016: 411). Daha sonraki süreçte özellikle 1950 ve 1960 yılları arasındaki dönemde Batı Avrupa ülkeleri geri kabul antlaşmalarıyla birbirlerinin bölgelerine olan göçleri düzenlemişlerdir. Son dönem olarak ifade edilen 1990'ların başında ise Avrupa'nın geri kabul politikası büyük oranda şekillenmeye başlamıştır. Söz konusu bu anlaşmalar her ne kadar düzensiz göçü önleme adına imzalanmış olsa da ilerleyen süreçte bu anlaşmaların geri gönderilmeme ilkesine aykırı olarak uygulandığı ortaya çıkmıştır (Hacıoğlu, 2016: 411). Geri kabul anlaşmalarının $\mathrm{AB}$ göç politikasında önemli bir yere sahip olduğunu bilinmektedir. $\mathrm{Bu}$ anlaşmalar yolu ile $\mathrm{AB}$, düzensiz göç ile mücadele ve sınır kontrollerine odaklanan bir yaklaşım benimsemekte, buna bağl1 olarak da düzensiz ve kitlesel göç ile mücadelede üçüncü ülkelere de sorumluluk yüklemeye çalışmaktadır (Çelik, 2014: 2). Bu doğrultuda Avrupa Birliği şimdiye kadar 18 ülke ile geri kabul anlaşması imzalamıştır. İmzalamış olduğu bu 18 anlaşmanın 15'i yürürlüğe girmiştir. $\mathrm{Bu}$ anlamda imzalanan ilk anlaşma Fas ile 1996 yılında olurken son anlaşma ise, 2014 yılında Azerbaycan ile yapılmıştır (Çelik, 2014: 2).

Geri kabul anlaşmalarının birçok açıdan sığınmacıların uluslararası hukuktan kaynaklanan temel haklarını kısıtladığı yönünde değerlendirmeler yapılmaktadır. AB kendine iltica başvurusunda bulunan Suriyeli mültecilerin bu başvurularını bireysel olarak değerlendirmek yerine toplu bir şekilde değerlendirmede bulunarak anlaşma imzaladığı ülkeye geri göndermektedir. Söz konusu bu geri göndermeler genellikle hızlandırılmış prosedür ile yapılmaktadır. Bu prosedür insan hakları ve uluslararası koruma hukuku yönünden kimi kaygılar yaratabilmektedir (Göçmen, 2014: 39). Çünkü iltica edenler arasında gerçekten uygun koşullara sahip sığınmacıların hakları çiğnenmektedir. Diğer yandan sığınmacılar toplu şekilde sınır dışı edildiğinde iltica başvurusu yapma ve bu başvuruyu izleme, savunma gibi haklardan da yoksun kalmaktadırlar. Sığınmacıların uluslararası hukukun en önemli prensiplerinden "geri gönderme yasağı" ilkesinden de yararlandırılmamaktadırlar. Geri kabul anlaşmalarının diğer bir yönü uygun koşullara sahip olmayan ülkelerle de yapılıyor olmasıdır. Örneğin Türkiye Cenevre Sözleşmesine coğrafi çekince koyduğu için Avrupa dışından gelen sığınmacılara iltica hakkı tanımamaktadır. Buna rağmen Suriyeli sığınmacılarla ilgili AB, Türkiye ile Geri Kabul anlaşması imzalamıştır. Buradan AB'nin sığınmacıları kendi sınırları dışında tutmak için temel değer olarak benimsediği hukukun üstünlüğünü de göz ardı edebilmektedir.

AB Göç Politikasının kitlesel göçlere karşı geliştirdiği ikinci çözüm “Avrupa Komşuluk Politikası”dır. Tam üyelik olmasa bile, Birliğin politik, ekonomik ve sosyal değerleri çerçevesinde komşu ülkelerin entegrasyonunu içerecek derecede ileri bir vizyona sahip bu politikanın ortaya çıkması, esas olarak Birliğin karşı karşıya kaldığı çok önemli sorunların çözülmesi ve yine Birliğin bazı global stratejilerini uygulama amaçlarına yöneliktir. Birinci amaç açısından, özellikle Birliğin maruz kaldığı yasadışı göç, uyuşturucu ve kadın ticareti ile enerji açığı sorunlarını çözmede kullanılması öngörülen Avrupa Komşuluk Politikası; ikinci amaç açısından da Birliğin nüfuz alanını genişletme ve global dengelerde 
söz sahibi olma hedeflerinin bir aracı olarak planlanmaktadır (Samur, 2009: 163). Günden güne daha da artan oranda ve çeşitli yollarla $\mathrm{AB}$ topraklarına giren yasadışı göçmenlerin ya da aynı kapsamda yükselen kadın ve uyuşturucu ticaretinin engellenmesi amacıyla $A B$, sınır kontrollerine ve Birlik topraklarına hatta yasal girişlerde ve vize başvurularında bile daha fazla titizlik göstermeye başlamıştır. Ancak sadece kapıları kapatarak ve polisiye tedbirlere dayanarak dışarıda bırakmaya çalışmakla sorunlar çözülmüş olmayacaktır. Tam aksine, AB ülkelerinin sınır kontrollerini karadan ve denizden artırmaları, ne pahasına olursa olsun Birlik topraklarına gelmeyi göze alan insanların, daha riskli yolları denemeye çalışmaları ve yolculuk sırasındaki can kayıplarının artmasıyla sonuçlanmaktadır. İşte, jeopolitik konumları nedeniyle söz konusu sorunların AB'nin başını ağrıtmasında önemli yeri olan periferi ülkelerle, yeni bir anlayış ve dinamizmle işbirliğine gidilmesini ifade eden Avrupa Komşuluk Politikası bu tek boyutlu politikanın çözüm için yeterli olmayacağının anlaşılması üzerine hayata geçirilmiştir. Diğer amaçları bir yana yasadışı yollarla insanların AB'ye akın etmelerinin önüne geçilmesini, başlangıçta Avrupa Komşuluk Politikasının tek varlık sebebi olarak görenler de vardır. Sınırın diğer tarafında kalan ya da uzak coğrafi alanlarda biriken sorunların, daha fazla içeriye yansımaması için, bir yandan söz konusu sorunların bulundukları coğrafyalarda kökten çözüme kavuşturulması (komşuların kendi aralarındaki işbirliğini artırma çabaları, oralarda ekonomik-politik yapıların değişimi için destek olma); diğer yandan da ortak tedbirlerle, hali hazırdaki yasadış1 faaliyetlerin önlenmesi (kaçak insan ve uyuşturucu ticaretine karşı önlem alma, sahte belgelerle girişi önleme, suç örgütleriyle mücadele ve meşru sebeplerle AB'ye gelmek isteyenlere vizede kolaylık sağlama gibi) amaçlanmaktadır. Bir anlamda en iyi savunma hücumdur prensibine göre hareket eden $\mathrm{AB}$, sorunları karşı alanlardaki kaynağında hallederek kendisine yönelen baskıların azaltılmasını ve böylelikle de Birlik alanının inşasının daha kolay yapılmasını hesap etmektedir (Samur, 2009:179-181).

AB göç politikasının kitlesel göç akınları karşısında geliştirdiği çözümlerden bir diğer "Güvenli Üçüncü Ülke" uygulamasıdır. Güvenli üçüncü ülke; bir mültecinin başka bir ülkede iltica talebinde bulunmadan önce bulunduğu, iltica ettiği ya da iltica talebinde bulunmasa da ilk iltica talebini değerlendirmeye uygun koşullara sahip olan ülkedir (Dal, 2016: 1). Bu kavram Avrupa birliği asgari standart ve usuller yönergesinin 26. ve 27. Maddelerinde düzenlemiştir (Turan ve Şaşkın, 2017: 52). Yönergenin 27. Maddesinde güvenli üçüncü ülke olarak tanımlanacak olan ülkenin hangi kriterlere de sahip olması gerektiğini düzenlemiştir. Buna göre bu kriterler şunlardır:

- Kişilerin hayatı ve özgürlüğü, ırk, din, tabiiyet, belirli bir sosyal gruba üyelik ya da siyasi düşünce esasında tehlikeye girmeyecektir ve

- Cenevre Sözleşmesi uyarınca non-refoulement ilkesine saygı duyulacaktır ve

- Uluslararası hukukta şart koşulan işkence ve zalimane, insanlık dışı ya da küçük düşürücü muameleye maruz bırakılmama hakkı ihlal edilerek kişinin gönderilmesi yasaklanacaktır ve

- Mülteci statüsü talep etme olasıllğı bulunması ve kişinin mülteci olarak nitelendirilmesi durumunda, Cenevre Sözleşmesine uygun olarak koruma elde etme olasıllı̆̆ mevcuttur. (İltica ve Göç Mevzuat1, 2005).

Güvenli üçüncü ülke kavramına göre iltica hakkı için bir devlete başvuran kişi, bu başvuruyu daha önce "güvenli" sayılan başka bir ülkede de yapma imkânına sahip olmuşsa, başvurusu reddedilir (Peker ve Sancar, 2007: 36). Buradan da anlaşılacă̆ı üzere güvenli üçüncü ülke statüsü ile birlikte Avrupa Birliği mültecilerin en temel hakkı olan iltica başvurusunda bulunurken seçim yapmasını engellemektedir. Bunun yanında güvenli üçüncü ülke uygulamasına bakıldığında sadece mültecilerin iltica başvuruları açısından değil aslında yapısı bakımından da sakıncalı olduğu görülmektedir. Çünkü yasaları ne kadar demokratik olursa olsun her ülkede baskı ve buna benzer olaylar görülebilmektedir. Ayrıca güvenli üçüncü ülkenin siyasi yönelimlere de açık olabileceği unutulmamalıdır (Turan ve Şaşkın, 2017: 53). Çünkü bunu belirleyen ülkeler kendi çıkarları doğrultusunda söz konusu olan kriterleri sağlamayan bir ülkeyi bile güvenli üçüncü ülke olarak tanımlayabilmektedirler (Peker ve Sancar, 2007: 37). Örneğin göçmenler konusunda en katı tavrı izleyen üye ülkelerden biri olan Macaristan, BM Mülteciler Yüksek Komiserliği'nce güvenli görülmeyen Sırbistan'1 Temmuz 2015'te güvenli üçüncü ülke ilan ederek 
sığınmacıları kayıt altına dahi almaksızın bu ülkeye göndermeye teşebbüs etmiştir (Ekinci, 2016: 32). Güvenli üçüncü ülke uygulaması her ne kadar kamuoyuna mülteciler adına olumlu gösterilse de gerçekte bu uygulamanın mülteciler adına pekte bir fayda sağlamadığı görülmektedir. Söz konusu bu uygulama ile sığınmacıların hukuki hakkı olan iltica hakları ellerinden alınarak toplu olarak Avrupa sınırlarından geri gönderilmektedirler. Güvenli üçüncü ülke uygulaması özellikle sığınmacıların Avrupa Birliği'ne iltica hakkını elinden almaktadır. Güvenli üçüncü ülke olarak tanımlanan bazı ülkeler aslında söz konusu güvenli ülke kriterlerini taşımamaktadır. Her ne kadar Avrupa Birliği, mülteci sorununa çözüm arayış1 içinde gibi görünse de uygulamış olduğu geri kabul ve güvenli üçüncü ülke uygulamaları ile birlikte aslında temel amacının mültecileri kendi sınırından uzak tutmak olduğu açıkça anlaşılmaktadır. Bunun içinde sığınmacıların iltica başvurularını değerlendirmeyi toplu olarak ele alarak onları güvenli ülke olarak tanımladığı aslında çoğunun da bu kriterlere uymadığını ülkelere göndermektedir (Turan ve Şaşkın, 2017: 53).

Yapılan değerlendirmelerde AB'nin göç ve sığınmacı sorununun temeline inmediği, soruna yönelik giderek daha kısıtlayıcı ve kısa vadeli çözümler aradığını, çözümleri üçüncü ülke topraklarına yönelttiğine vurgu yapılmaktadır (Canpolat ve Arıner, 2012: 14). Bunun için de "güvenlikleştirme" ve "dışsallaştırma" kavramlarını öne çıkarmaktadır. "Güvenlikleştirme" belli bir politika alanında resmi ve yerleșmiş mekanizmaların dıșına çıkarak olağanüstü önlemler almayı meşrulaștırmak için o konunun olağandışı bir tehdit unsuru haline getiren kavram olarak tanımlanmakta ve birçok araştırmacı tarafindan AB göç yönetiminin gelişimini anlamlandırmak için kullanılmıştır (Arslan, 2012: 44-60). Schengen Anlaşmaları ve Avrupa Polis Ofisi (EUROPOL) gibi mekanizmaların Avrupa göç politikasının zeminini hazırlayan güvenlikleştirme adımları olarak değerlendirilmektedir. $\mathrm{AB}$ göç yönetiminde uygulanan politikayı ifade eden diğer bir kavram da "dışsallaştırmadır". Dışsallaştırma, göç denetiminin Avrupa'nın sınırlarının dışında yapılması, yani göçmenler için seçilen hedef ülkelerden uzakta yapılması için $\mathrm{AB}$ göç sınırlarının taşınması durumunu ifade etmektedir (Güleç, 2015: 91). Güvenlikleştirme politikalarının bir devamı olarak nitelendirilen dışsallaştırma politikaları $\mathrm{AB}$ tarafindan Schengen Anlaşmaları çerçevesinde kabul edilen vize politikalarının yanı sıra, taşımacılık cezaları ve havaalanı irtibat yetkilileri bulundurma zorunluluğu ile birlikte göç yönetimini üçüncü ülkelerin sınırlarına taşımıştır (Güleç, 2015: 91).

\section{SONUÇ}

AB göç politikası, birliğin ekonomik, sosyal ve politik öncelikleri doğrultusunda şekillenmiştir. Pek çok alanda ortak politik duruş sergilemeyi başaran $\mathrm{AB}$ üyesi ülkeler, göç konusunda bu başarıyı sağlayamamışlardır. Birlik üyesi ülkelerin farklı ekonomik ve sosyal yapıya sahip olmaları, alınan kararlara ilişkin uygulamaları kendi iç hukuklarına aktarma noktasındaki isteksizlikleri, kararların uygulanıp uygulanmadığını denetleyecek bağımsız bir mekanizmanın bulunmaması gibi sebepler AB'nin göç konusunda ortak politika geliştirmesini zorlaştırmıştır.

Ortak bir göç politikası oluşturulamamasına rağmen AB'nin özellikle kitlesel göç akınları karşısındaki tutumu hayal kırıklığı yaratmıştır. Çünkü özellikle Orta doğudaki iç karışıklıklar nedeniyle canını kurtarmak için Birlik kapısına dayanan sığınmacılarla ilgili gerçekleştirilen uygulamalar AB'nin temel değerleriyle taban tabana zitlık teşkil etmektedir. Kurulduğu yıllardan itibaren insan haklarına saygı, çok kültürlülük, hoşgörü, hukukun üstünlüğü gibi evrensel değerlerle kendini tanımlayan $\mathrm{AB}$, sığınmacılarla konusunda dışlayıcı, reddiyeci bir tutum sergilemiştir. Kitlesel sığınma talepleri karşısında hayata geçirdiği geri kabul anlaşmaları, komşuluk politikaları ile güvenli üçüncü ülke uygulamaları, göç meselesini her halükarda Birlik sınırlarının dışında tutma, sorumluluk ve inisiyatif almama yönünde pozisyon aldığını ortaya koymuştur. Diğer yandan söz konusu uygulamalar sayıları milyonlarla ifade edilen sığınmacının temel hakkı olan iltica haklarını ellerinden almakta ve hiçbir değerlendirmeye tabi tutmadan onları çaresizliğe itmektedir. Söz konusu uygulamalar, hem AB'nin tabi olduğu Cenevre Sözleşmesi’ne hem de geri göndermeme ilkesine aykırılık teşkil etmektedir.

Avrupa Birliği’nin bu gibi uygulamalardan vazgeçerek daha yapıcı ve daha kalıcı politikalar üretmesi, insan hakları ihlallerinin en aza indirilmeye çalışılarak ve dengelerin doğru dağıtıldığı bir ortaklık International Journal of Political Studies, December 2017, Vol 3, Issue 3 
zemininde vicdanlı bir diyalog çerçevesinde hareket edilmesi, milli çıarların ön planda tutulduğu bir yaklaşımdan öte tüm insanlık için faydalı olabilecek kararlar alınması, göç kontrolü yerine göç politikaları; güvenlik yerine entegrasyon anlayışının benimsenmesi, AB'nin sahip olduğunu iddia ettiği demokrasi ve insan hakları gibi değerler üzerinden yürütülerek söz konusu değerlerle uyumlu politikalar üretilmesinin uzun vadede herkes için yararlı olacağı değerlendirilmektedir

Göç bugün engellenemeyen, önüne geçilemeyen bir hakikattir, bir süreçtir. Bütün engelleme çalışmaları, artan sınır kontrolleri, dikenli teller, yüksek duvarlar, sığınmacı sayısını ya da göçü azaltmamakta; aksine düzensiz göçü daha da arttırmaktadır. Ülkelerin, yönetimlerin, göçü engellemek için harcadıkları kaynakları göçmenlerin sorunlarını çözmeye harcamaları daha etkili ve sağlılı sonuçlar ortaya koyacaktır. 


\section{KAYNAKÇA}

AKALIN, Hilal (2013), Avrupa Birliği Üyelik Sürecinde Türkiye'de Mülteci Hukuku: Suriye Örneği, Yayımlanmamış Yüksek Lisans Tezi, Beykent Üniversitesi, İstanbul.

CANPOLAT, Hasan ve ARINER Hakkı Onur, (2012). Küresel Göç ve Avrupa Birliği ile Türkiye'nin Göç Politikalarının Gelişimi. ORSAM Rapor No:123. Ankara.

ÇELİK, Ahmet.(2014), Türkiye - AB Geri Kabul Anlaşması, Konya Ticaret Odası, Etüt - Araştırma Servisi.

DAL, Sevil (2016), Güvenilir Ülke Statüsü, http://www.nokta32.com/yazar-368 güvenilir_ulke_statusu.html, (19.01.2017).

DÜRGEN, Betül (2015), Türkiye'deki Suriyelilerin Hukukî Durumu, Yayımlanmamış Yüksek Lisans Tezi, Akdeniz Üniversitesi SBE, Antalya.

EKİNCí, Uğur. M. (2016), Türkiye-AB Geri Kabul Anlaşması ve Vize Diyalogu, Seta, İstanbul.

EKŞI, Nuray (2016), Yabancılar ve Uluslararası Koruma Hukuku, İstanbul: Beta Yayınları.

ELMAS, Fatma Yılmaz (2016), Avrupa Birliği Göç-Dış Politika İlişkisinde Paradigma Değişimi, Yayımlanmamış Doktora Tezi, Ankara Üniversitesi SBE, Ankara.

GENÇLEr, A., (2005), “Avrupa Birliğinin Göç Politikası”, Sosyal Siyaset Konferansları, Prof.Dr. Turan Yazgan'a Armağan Özel Sayısı 49. Kitap İstanbul Üniversitesi Yayın No:4566, İktisat Fakültesi Yayın No:582,173198, İstanbul

GÖÇMEN, İlke. (2014), Türkiye İle Avrupa Birliği Arasındaki Geri Kabul Anlaşmasının Hukuki Yönden Analizi, Ankara Avrupa Çalışmaları Dergisi, Cilt:13, No:2. Ankara.

GÜLEÇ, Cansu (2015), Avrupa Birliği’nin Göç Politikaları Ve Türkiye’ye Yansımaları, TESAM Akademi Dergisi, Temmuz 2015, 2 (2).

HACIOĞLU Fatma Zeynep, Geri Antlaşması. http://www.muharrembalci.com/hukukdunyasi/makaleler/birikimlerV/589.pdf. 24.01.2017.

HOPYAR, Zehra (2016), Avrupa'nın Mülteci Politikası, PESA Uluslararası Politik Araştırmalar Dergisi, Cilt:2, Sayı 3.

İltica ve Göç Mevzuatı (Şubat 2005), Ankara.

KİRişÇi, Kemal (2002). Avrupa Kalesi mi, Dostça Schengen mi? Avrupa ve Türkiye'de Sığınma Hakkı ve Mülteciler Uluslararası Sempozyumu, Toplumsal Araştırmalar Kültür ve Sanat İçin Vakıf Yayınları, Ankara.

KÖKTAŞ, Arif (2011). Sınır Güvenlik Birimi Kurma Çalışmaları. SDE Analiz, Stratejik Düşünce Enstitüsü, Ankara.

ÖZCAN, Mehmet (2005). Avrupa Birliği Siğınma Hukuku, Ortak Bir Siğınma Hukukunun Ortaya Çıkışı. Uluslararası Stratejik Araştırmalar Kurumu. Ankara,

PEKER Bülent, SANCAR Mithat (2007), Mülteciler ve İltica Hakkı, İnsan Hakları Derneği İktisadi İşletmesi Yayınları, Ankara.

SAMUR, H. (2008). Avrupa Birliği’nde Göçe Yönelik Global Yaklaşım. Uluslararası İnsan Bilimleri Dergisi, 5(2).

SAMUR, Hakan (2009) “Avrupa Komşuluk Politikası ve Amaçları”, Elektronik Sosyal Bilimler Dergisi Kış-2009 C.8 S.27 (018-035). 
SAVAŞAN, Zerrin (2009). “AB'de Sığınma Hakkı: Ortak Sığınma Sistemi Oluşturma Amacı ve Devam Eden Kısıtlamalar”. İnsan Hakları Yıllığı, 27, 13-34.

SOMUNCU, B. (2006). Türkiye'nin Avrupa Birliği'ne Tam Üyelik Sürecinde Uluslararası Göç Politikası. (Yayınlanmamış Yüksek Lisans Tezi), Dokuz Eylül Üniversitesi, İzmir.

SÖNMEZ, Pelin (2015). Avrupa Birliği’nde Yeni Dönem Postkolonyal İlişkiler ve Göç Politikaları Diyaloğu, (İstanbul Üniversitesi Sosyal Bilimler Enstitüsü, Doktora Tezi).Avrupa Birliği Bakanlığ1 Yayınları, Ankara.

TANERİ, Gökhan (2012). Uluslararası Hukukta Mülteci ve Sığınmacıların Geri Gönderilmemesi (NonRefoulement) İlkesi, Yayımlanmamış Yüksek Lisans Tezi, Selçuk Üniversitesi, Konya.

TURAN, Yıldırım ve ŞAŞKIN Osman (2017), “AB’ye İltica Başvurularının Değerlendirilmesinde Geri Kabul ve Güvenli Üçüncü Ülke Tartışmaları”, PESA Uluslararası Sosyal Araştırmalar Dergisi Şubat 2017, Cilt:3, Sayı 1

ÜNLÜ, Güler (2007). Uluslar Arası Göç ve Göçmenliğin Değişen Koşulları İçinde Mültecilik, Yayımlanmamış Yüksek Lisans Tezi, Muğla Üniversitesi SBE, Muğla. 